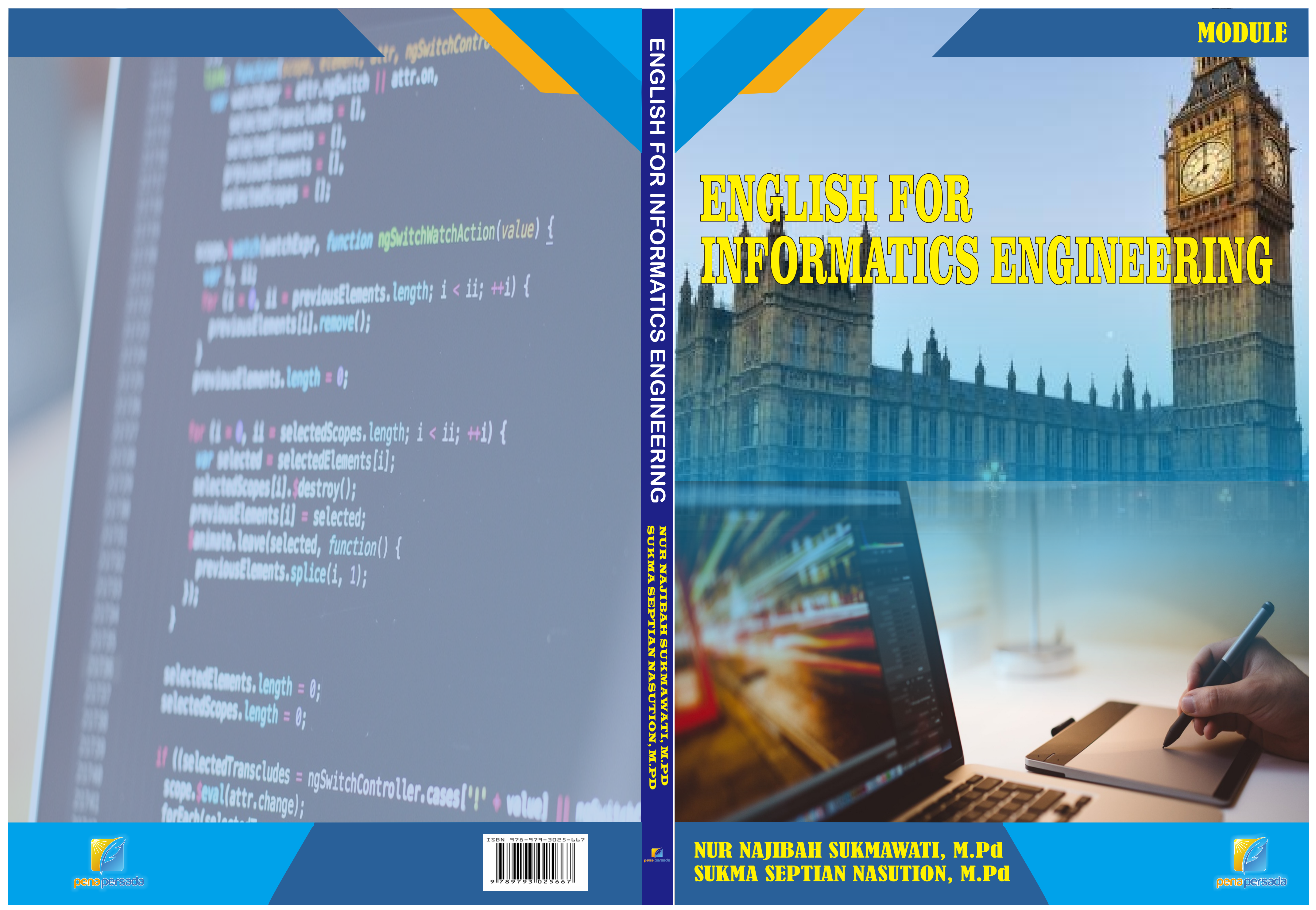




\section{ENGLISH FOR INFORMATICS ENGINEERING}

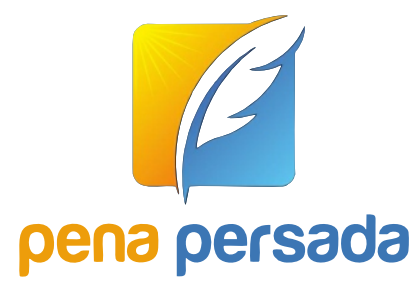

NUR NAJIBAH SUKMAWATI, M.Pd SUKMA SEPTIAN NASUTION, M.Pd 


\title{
ENGLISH FOR INFORMATICS ENGINEERING
}

\author{
Penulis \\ NUR NAJIBAH SUKMAWATI, M.Pd \\ SUKMA SEPTIAN NASUTION, M.Pd
}

Desain Sampul

Fajar T. Septiono

Penata Letak

Aan Saeful Islam

\section{Penerbit CV. Pena Persada}

Jl. Gerilya No. 292 Purwokerto Selatan, Kab. Banyumas

Jawa Tengah

Email: penapersada@gmail.com

Website : penapersada.com Phone : 0857-2604-2979

Hak cipta dilindungi oleh Undang-undang. Dilarang memperbanyak karya tulis ini dalam bentuk apapun tanpa seijin dari penerbit.

All rights reserved.

Cetakan pertama : 2019

ISBN : 978-979-3025-66-7 


\section{KATA PENGANTAR}

Dalam perkembangannya, bahasa Inggris telah menjadi salah satu bahasa utama di berbagai konteks kehidupan, baik itu formal maupun informal, lisan maupun tulisan, interpersonal maupun transaksional. Hal ini mendorong dunia pendidikan untuk mengembangkan pembelajaran Bahasa Inggris baik sebagai disiplin ilmu maupun sebagai media untuk belajar keilmuan lainnya. Bahasa Inggris sebagai disiplin ilmu mencakup ilmu linguistik maupun budaya. Adapun bahasa Inggris sebagai media belajar ditujukan untuk memperdalam pemahaman terhadap bidang keilmuan lain yang disajikan dalam bahasa Inggris.

Di ruang lingkup universitas, pembelajaran bahasa Inggris diarahkan kepada kemampuan berbahasa Inggris untuk tujuan akademik yang dapat menunjang kemampuan program studi yang dipilih mahasiswa, termasuk program studi Teknik Informatika. Prodi Teknik Informatika memerlukan bahasa Inggris bukan hanya sebagai alat untuk berkomunikasi, namun juga sebagai media untuk mempelajari berbagai literatur dari berbagai negara yang disajikan dalam bahasa Inggris.

Maka dari itu, bahan ajar bahasa Inggris untuk Teknik Informatika ini disusun untuk memenuhi kebutuhan spesifik mahasiswa Teknik Informatika. Materi bahan ajar ini disusun dengan menggunakan pendekatan berbasis genre yang diharapkan mampu untuk meningkatkan kemampuan bahasa Inggris mahasiswa. Tema yang disajikan dalam modul ini dibagi kedalam tiga genre yang dibahas secara mendalam, yaitu argumentation text, explanation text, dan procedure text. melalui pendekatan ketiga jenis teks ini diharapkan mahasiswa mampu menerapkan kemampuan bahasa Inggris untuk menunjang karirnya di masa depan. 
Penulis menyampaikan rasa terima kasih epada Direktorat Jendral Riset dan Pendidikan Tinggi atas bantuan pendanaan sehingga modul ini bisa diwujudkan serta kepada LPPM Universitas Pamulang yang telah mendukung pelaksanaan penelitian pengembangan ini, serta rasa cinta yang teramat dalam kepada putri kami, Ghaisani Ayesha Nasution yang terus menjadi penyemangat kami untuk berkontribusi di dunia pendidikan Bahasa Inggris.

Hormat Kami

Nur Najibah Sukmawati

Sukma Septian Nasution 


\section{DAFTAR ISI}

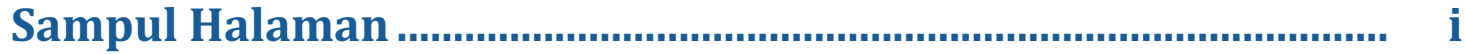

Kata Pengantar .......................................................................... ii

Daftar Isi ..................................................................................... iv

\section{CHAPTER 1}

DO COMPUTERS BRING MORE HARM THAN GOOD? ...................... 1

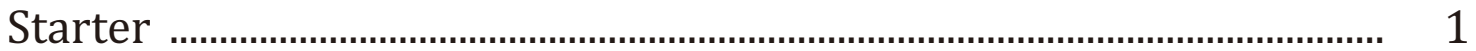

Language Features .....................................................................................

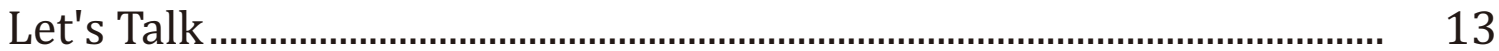

\section{CHAPTER 2}

HOW THIS AND THAT ARE MADE ......................................................... 20

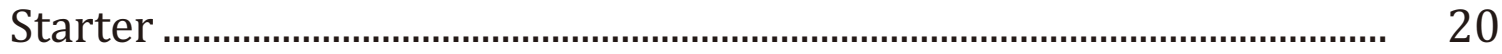

Language Features...................................................................................... 23

Let's Talk

\section{CHAPTER 3}

HOW TO DO THIS AND THAT ...................................................................... 35

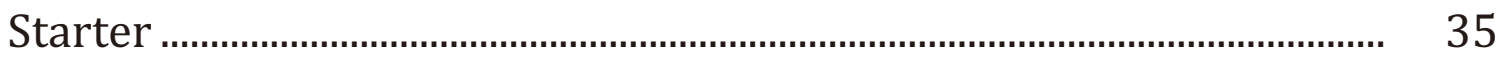

Language Features.................................................................................... 39

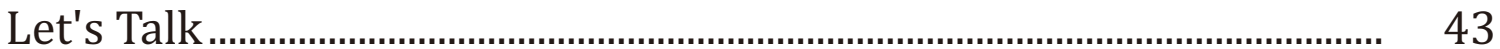




\section{HAPTER 1}

DO COMPUTERS BRING HARM MORE THAN GOOD?

\section{Starter}

Text 1

\section{COMPUTERS AND ITS ROLE}

Modern lives are symbolized by the existence of technology which aims at simplifying human's activities and one of the most widely-used technologies is computer. People use computer in many kinds of daily activities such as working, learning, and even playing. How benefitted are people by the existence of computers?
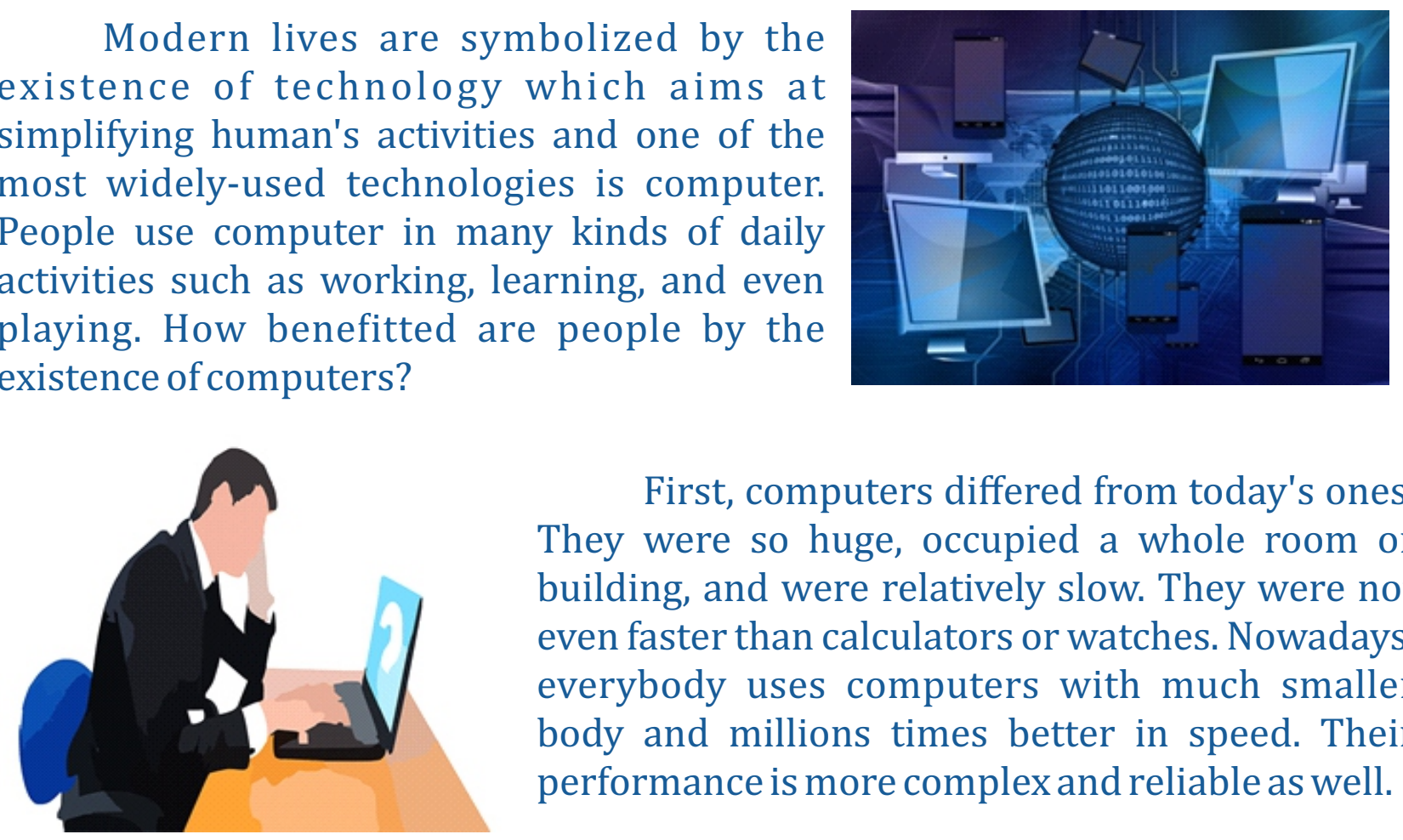

First, computers differed from today's ones. They were so huge, occupied a whole room or building, and were relatively slow. They were not even faster than calculators or watches. Nowadays, everybody uses computers with much smaller body and millions times better in speed. Their performance is more complex and reliable as well.

Second, computers help many significant aspects of life. In medicine, for instance, computers enable modern medical intelligence to diagnose diseases fast, effectively, and thoroughly. In banking system, computers are irreplaceable. They control ATMs, all data is stored on special hard disks where we do not even need paper to use anymore. Furthermore, architects, designers and engineers can't imagine their work without computers. These machines are helpful in making their jobs feasible. We depend on them also in such fields as criminology. They help police to solve crimes and collect evidence. Moreover, computers are vital in education. With a help of internet, they store enormous amount of data which helps students to gain information. They have become so popular that students not knowing how to use them are to be illiterate.

All the superb features of computer do not mean it a completely good means to work with. There is also dark side of computer technology. However, as long as we can use it properly, this technology is beneficial to human life. 


\section{Enlist what you are used to doing with computers}

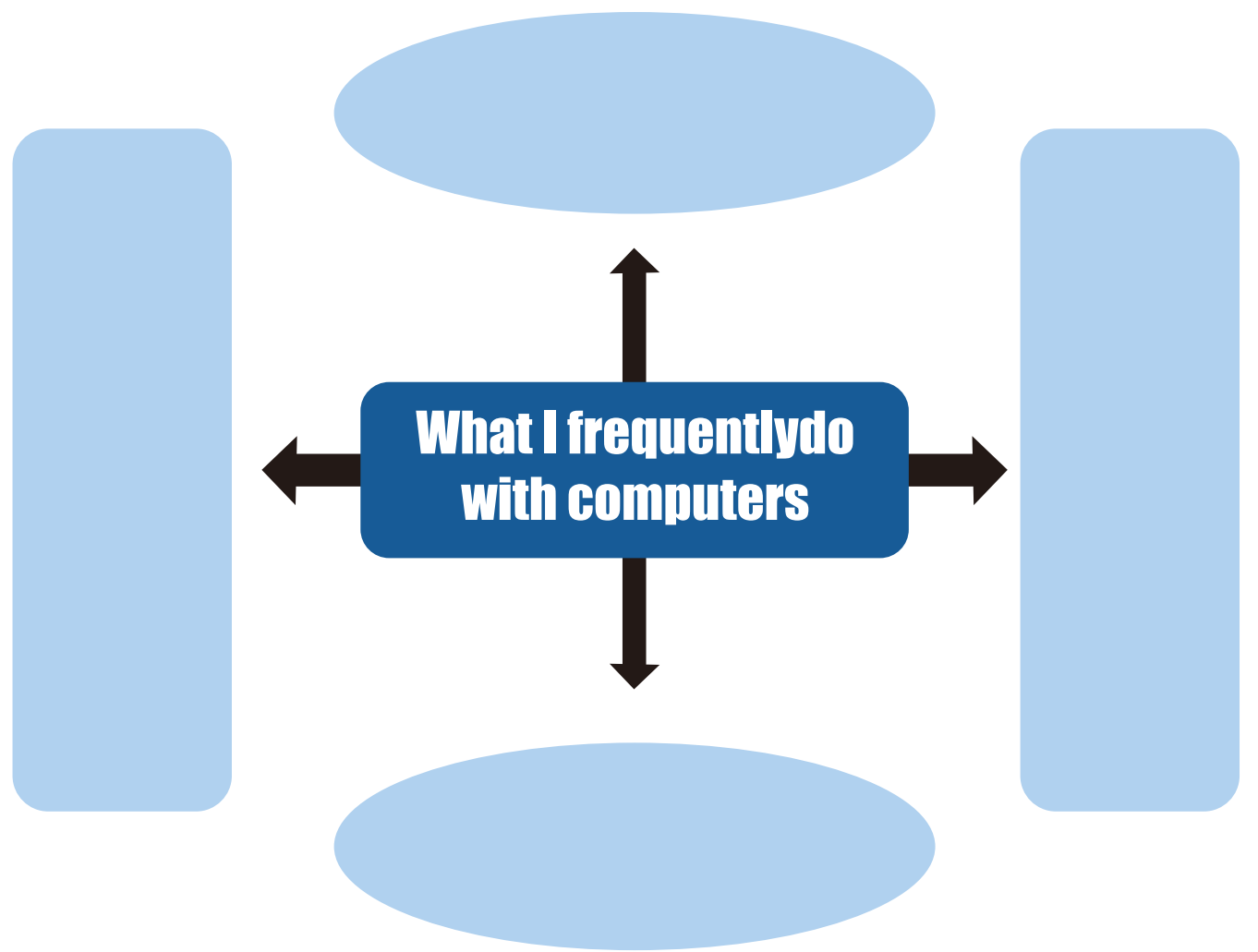

\section{Discuss the following questions.}

1. Do you prefer reading by a tablet to reading by a textbook?

2. Do you totally/partially agree/disagree with the text? Why?

3. In your opinion, should lectures in university leave textbook in instructional process?

4. How effective it is when you read by tablet?

5. Have you ever personally compared whether reading by tablet is more effective than book or vice versa?

\section{Read the following text.}

Nowadays, the increasing demand on paper is not followed by the number of tree as the basic material to produce papers. This creates an issue of constraining the use of paper. Particularly, there is a debatable issue whether people need to transform their habit of reading from paper-based book to computers. Here are given two texts that confront the idea each other. 


\section{Text 2}

\section{COMPUTERS SHOULD NEVER REPLACE TEXTBOOK}

Many people think that computers should replace textbooks because they are cheaper. However, I believe that it should not because using computers decreases concentration, and creates physical health problems.

First, students' concentration would be greatly decreased as a result of using a computer rather than a course book. In contrast, you can guess that these students who didn't use computers for textbooks probably were much more focused and were able to concentrate and grasp the concept held within the schoolbook. I can actually relate to this concept within my own life To be completely honest, I normally did other things like listen to music or play games as I attempted to read the computerized book. Therefore, using the computer rather than a hardcover textbook showed many more distractions and much less concentration.
IT'S OVER, BOOK

YOU'RE AN INFERIOR TECHNOLOGY.

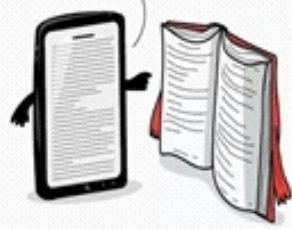

YOUR BIG, CLUNKY FORMAT IS IRRELEVANT

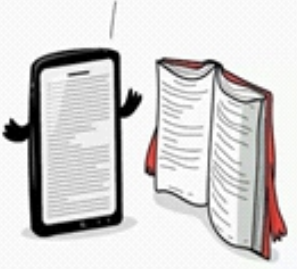

JUST A NIP OF THIS FLAME AND YOUD BE GONE FOREVER!
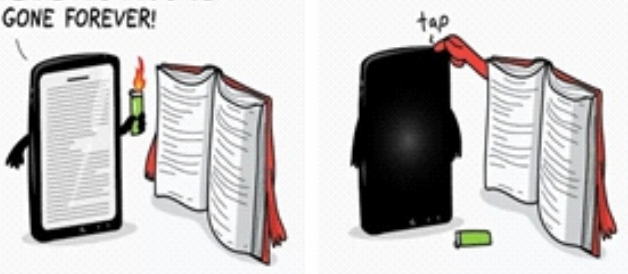

Treanviobvencon

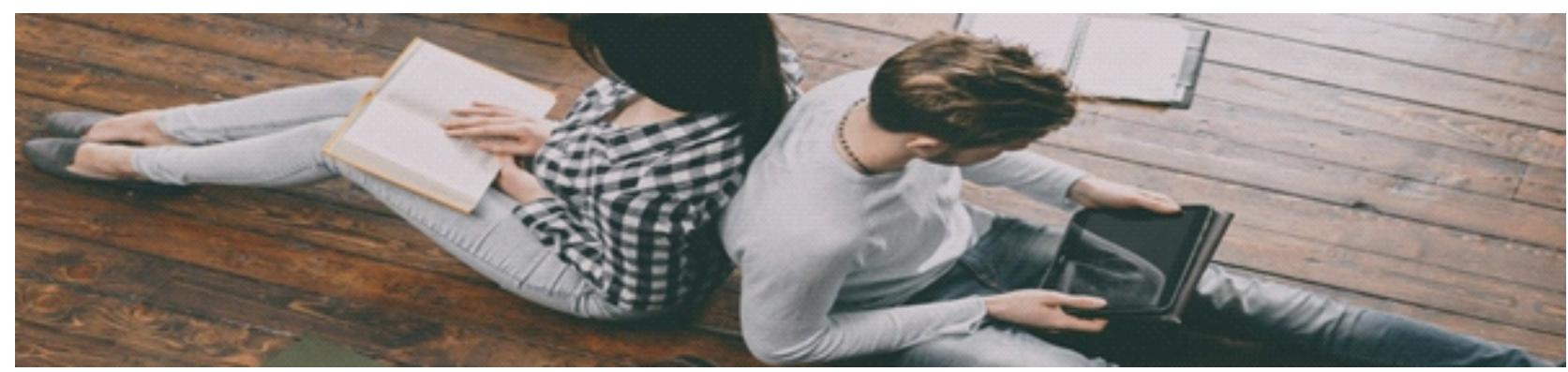

Second, replacing textbooks with computers would also jeopardize your physical health. According to the article, Computer-related Injuries, long periods of using a computer can increase your chance of developing an injury. After reading this, it reminded me of my mother. My mom works within the field of technology and 
computers. It is because she sits in front of the computer all day that she has obtained injuries. These injuries that she has gotten are: severe back and neck pain, horrid headaches, and even eyestrain. If schools were to replace textbooks with computers, kids would be at a higher risk of receiving: back/neck pain, headaches/migraines, shoulder/arm pain, muscle/tendon pain, eyestrain, and it could increase your risk of obesity. Therefore, by replacing textbooks with computers, you are also increasing the risk of injury.

Increasing computer use by replacing textbooks with them would only result in a disaster. Using computers rather than textbooks will reduce concentration, and increase the risk of injury. Technology is such a harmful thing; so why would we want to envelop our youth with it?

Source:

Source:

https://www.teenink.com/opinion/school_college/article/788497/Should-ComputersReplace-Textbooks

\section{True or False}

Put $(\sqrt{ })$ to a column that suits the statements based on Text 2.

\begin{tabular}{|ll|}
\hline No. & \multicolumn{1}{c|}{ Statement } \\
\hline 1 & The author agrees textbook should no longer be used to read. \\
\hline 2 & $\begin{array}{l}\text { The author gives } 3 \text { reasons to make people believe textbook } \\
\text { should/should not be replaced by notebook, }\end{array}$ \\
\hline 3 & $\begin{array}{l}\text { The author believes people reading by using notebook are easily } \\
\text { distracted. }\end{array}$ \\
\hline 4 & $\begin{array}{l}\text { The author tends to be interested to open YouTube while reading } \\
\text { by using notebook. }\end{array}$ \\
\hline 5 & $\begin{array}{l}\text { The author believes there is no relation with using notebook to } \\
\text { read with physical health. }\end{array}$ \\
\hline 6 & $\begin{array}{l}\text { The author mentions his mom as an example of the negative } \\
\text { impact of reading by using notebook. }\end{array}$ \\
\hline 7. & The author has positive attitude to technology. \\
\hline
\end{tabular}

\section{Text 3.}

\section{TABLETS SHOULD REPLACE TEXTBOOKS}

While the value and history of a textbook cannot be erased, it is definitely a thing of the past. Tablets have proved to be the most efficient learning tool as not only does it eliminate the burden of having to carry multiple books, but it also stimulates our brains. It is not that textbooks are outdated or that they are of less importance, but with the pace of technology and the human brain constantly evolving, tablets are simply better at keeping up with that pace. 
We were given tablets in school and it was a very happy moment for all students, but it was not only because we could download games and apps, rather because it was a time saver. It also improved our creativity, engagement and our grades as we were all aiming to find the information as fast as possible and with textbooks, that was simply never possible.

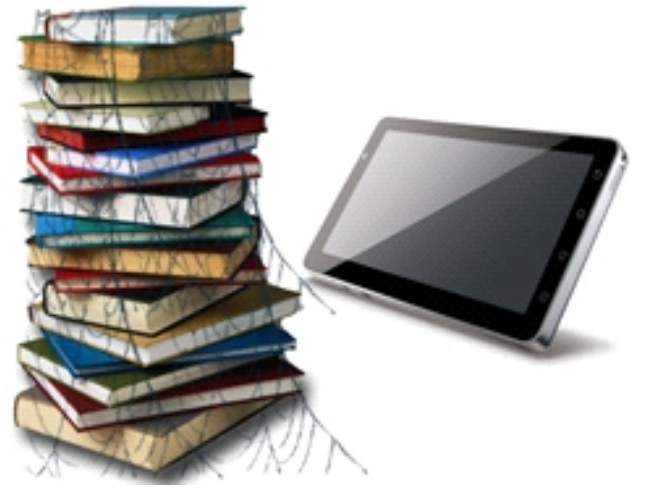

Critics argue that it is too much of a distraction in the classroom and that teachers cannot make sure that students are actually using it for educational purposes, but that can also be the case with textbooks. At the end of the day, whether or not a student uses his or her book or tablet for educational purposes, is his or her own loss.

The reason for the success of the tablet is because it is new, innovative and different from traditional teaching methods. So, instead of opposing the idea of tablets in the classroom, we need to support this because at the end of the day, the aim should be to maximize learning outcome while keeping the students engaged and interested in the subject.Text Source:

https://gulfnews.com picture: debate.org

\section{True or False}

Put $(\sqrt{ })$ to a column that suits the statements based on Text 2 .

\begin{tabular}{|ll|}
\hline No. Statement & True False \\
\hline 1 & The author agrees textbook should no longer be used to read. \\
\hline 2 & $\begin{array}{l}\text { The author gives } 3 \text { reasons to make people believe textbook } \\
\text { should/should not be replaced by notebook, }\end{array}$ \\
\hline 3 & $\begin{array}{l}\text { The author believes people reading by using notebook save } \\
\text { time more efficiently. }\end{array}$ \\
\hline 4 & $\begin{array}{l}\text { The author believes reading by using books can never prevent } \\
\text { the cause of distraction. }\end{array}$ \\
\hline 5 & $\begin{array}{l}\text { The author believes using notebook to read is a symbol of } \\
\text { appreciating technology era. }\end{array}$ \\
\hline 6 & $\begin{array}{l}\text { The author however does not give any suggestion to support } \\
\text { the use of notebook to read. }\end{array}$ \\
\hline 7. & The author has positive attitude to technology. \\
\hline
\end{tabular}




\section{Answer the following questions based on Text 3 .}

1. In what line can you find information about brain stimulation by using tablet?

2. The word "it" in line 3 refers to....

3. What does paragraph 2 mainly talk about?

4. In which paragraph can you find information about the strength of tablets in reading?

5. How is the writer's attitude to reading by text book?

7. Classify the structure of the two texts above into these following tables.

Title: Computers Should Never Replace Textbook

\begin{tabular}{|c|c|}
\hline Stagings & Text \\
\hline \multicolumn{2}{|l|}{ Introduction } \\
\hline \multicolumn{2}{|l|}{ Argument 1} \\
\hline \multicolumn{2}{|l|}{ Argument 2} \\
\hline \multicolumn{2}{|l|}{ Argument 3} \\
\hline
\end{tabular}

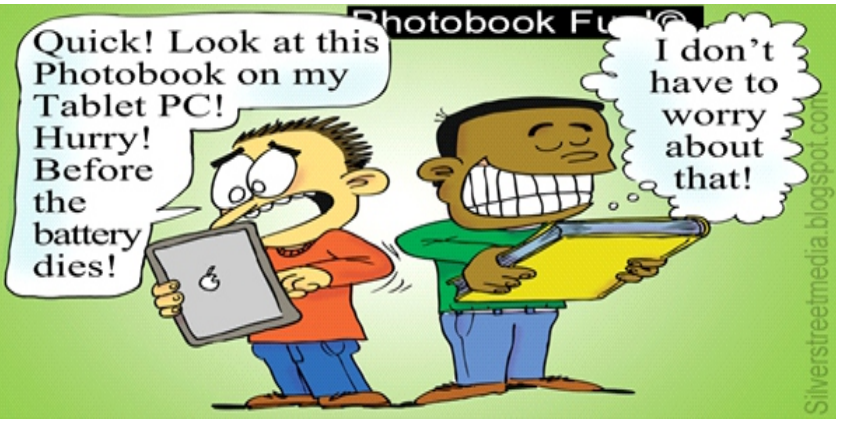




\section{Title: Tablets Should Replace Textbook}

Stagings

\section{Text}

\section{Introduction}

\section{Argument 1}

\section{Argument 2}

\section{Argument 3}

\section{Language Features}

\section{Complex Sentence}

In arguing, you are encouraged to be able to express your opinion in complex sentence. Complex sentence is a sentence that consists of one main clause and at least one dependent clause. To join these clauses, we need subordinate conjunction. Take a look at the following example.

Many people think that computers should replace textbooks because they are cheaper. Main Clause 


\section{Many people think}

S

$\mathrm{V}$

2. that computers should replace textbooks

$\begin{array}{llll}\text { Sub } & \mathrm{V} & \mathrm{V}\end{array}$

3. because they are cheaper

Sub S V C

$$
\begin{array}{lll}
\text { S }=\text { Subject } & \text { V } & =\text { Verb } \\
\text { O=Object } & \text { Sub } & =\text { Subordinator } \\
\text { C }=\text { Complement } & &
\end{array}
$$

The sentence consists of one main clause, and two dependent clauses. Each clause, either main or dependent, consists of subject and verb. The clauses are connected by subordinate conjunctions: that and because.

\section{Noun Clause}

Noun clause is a clause that acts as a noun. Noun clause serves as the subject or complement of the verb in a sentence. Example:

\section{What the boy said is not clear. Noun Clause}

\section{I like what you said Noun Clause}

\section{Functions:}

1. Subject to verb

Where he decided to go is none of my

Subject

business.

3. Complement to subject Here is where all begin.
2. Object to verb

I do not know where she lives. Object

4. Object of preposition The pilot deliberated on when the plan should land Complement Object of preposition 


\section{Nominal Group}

\begin{tabular}{|c|c|c|c|c|c|c|c|}
\hline Pre-N & fier & & & & & & Post-Modifier \\
\hline $\mathrm{D} \wedge$ & NUM & $\wedge$ & $\mathrm{E}$ & $\wedge$ & C & $\wedge \mathrm{T}$ & $\wedge 0$ \\
\hline
\end{tabular}

\section{Notes:}

Deictic : Articles, Possesive, Adjective

Numeric : Ordinal and cardinal number

Ephitet : Describing things by their shape, size, color, and physical or psychological condition (Adjective, present participle, past participle)

Classifier : Classifying things in terms of their kinds of types (noun, adjective, and gerund)

Qualifier : Additional information

Examples:

1. The first large teacher office which was built in 2005

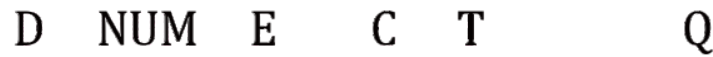

2. $\underline{\text { A beautiful classic melody }}$

D E $\quad$ C $\quad \mathrm{T}$

\section{Noun}

Noun refers to name of things, people, animal, or even something we cannot see. There are many kinds of noun. They are described in the following picture.

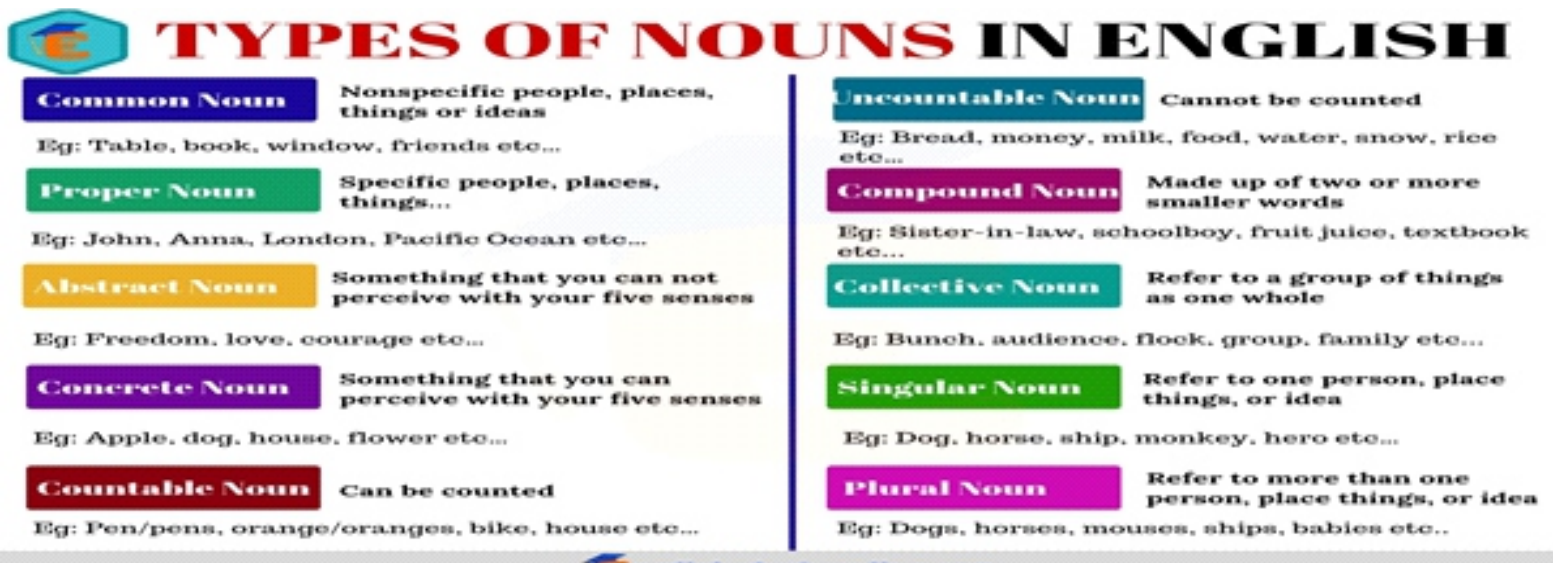




\section{Components of Computer}

Discuss functions of the following components of computer with your lecturer.

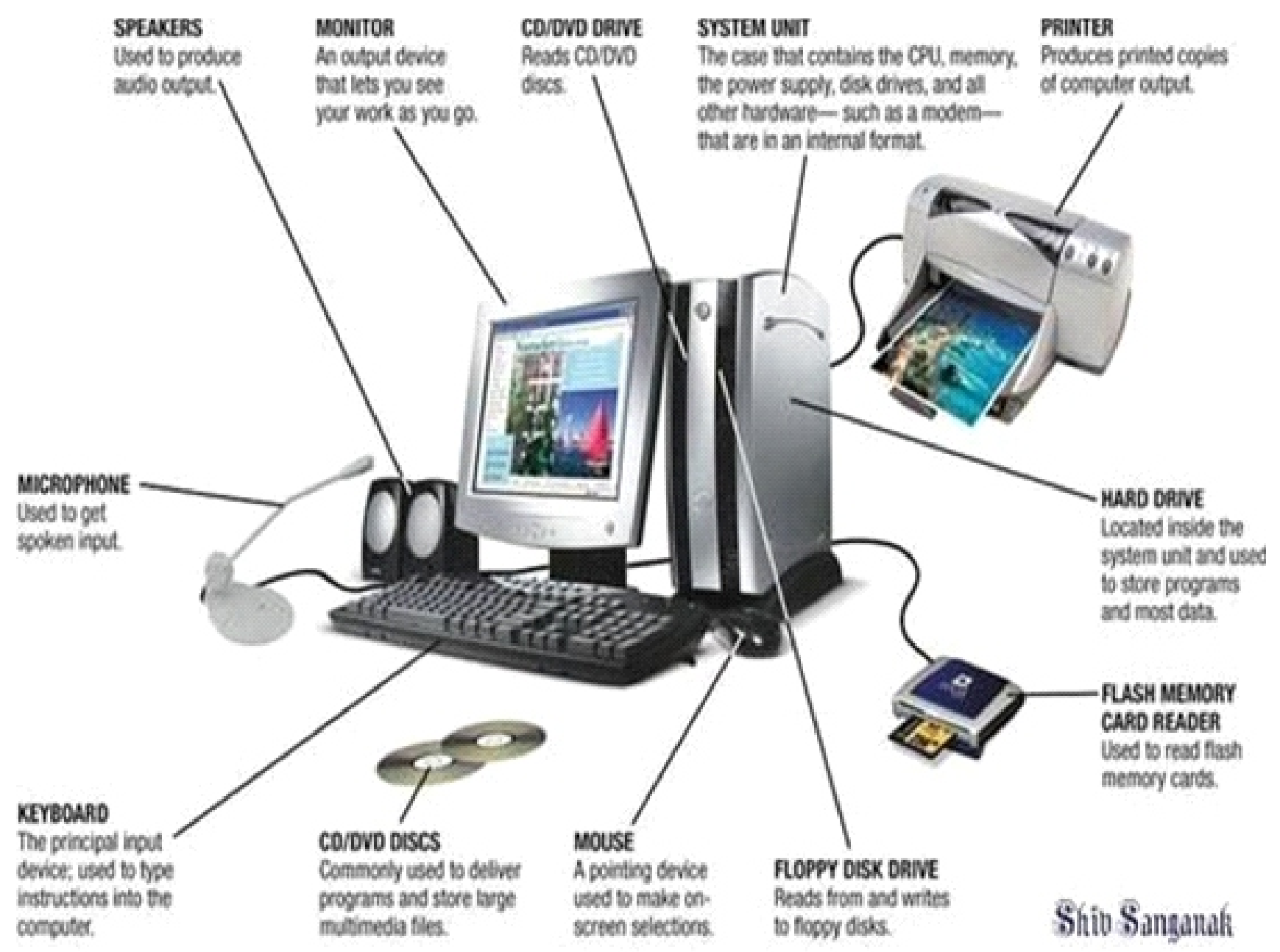

\section{Pronounce the following words together with your lecturer.}

Computer (/kəm'pju:tə/)

Efficiency (/I'frfənsi:/)

Elimination (/I'lımıneIJən/)

Engagement (/In'gerdzmn/)

Eraser (/I'reizr/)

Important (/im'pэ:tənt/)

Information (/ınfə'meIfən/)

Interest (/'intrist/)

Stimulation (/,stimju'lerjən/)

Value (/'vælju:/)

Technology (/tek'nolədzi/) keyboard (/'ki:bo:d/)

microphone (/'markrəfəun/)

memory (/'meməri/)

mouse (/maus/)

printer (/'printə/)

speaker (/'spi:kə/) 
10. Identify and analyze complex sentences in text 1,2 , and

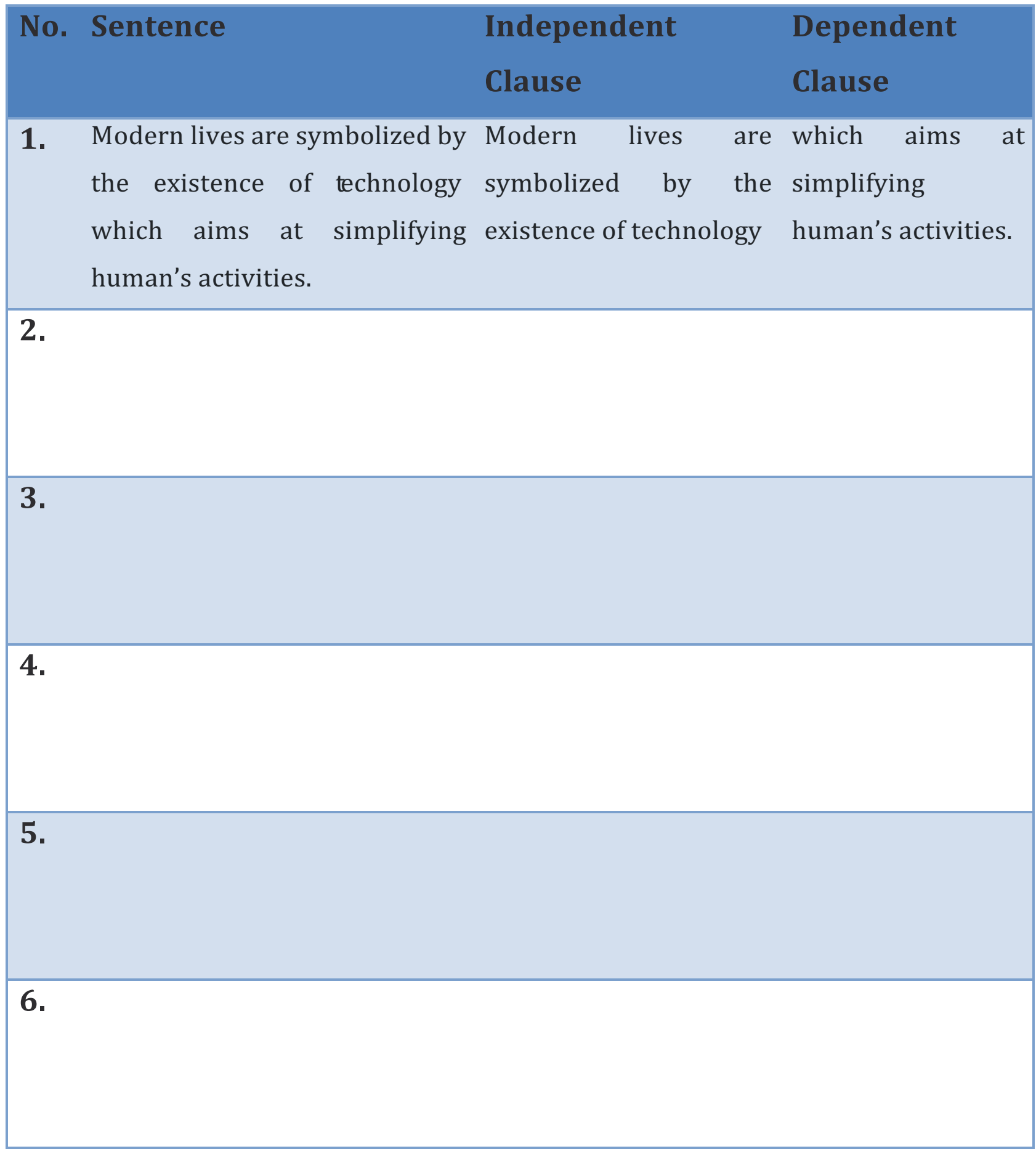

\section{Arrange the words in each number to make good sentences.}

1. argue - people - that - Many - is - it - distraction - the - in - classroom

2. a student - his or her - uses - Whether or not - book or tablet - for purposes - educational - is - loss - his or her.

3. people - that - Many - computers - think - replace - should - textbooks. 
12. After you arrange the sentences correctly, convert each sentence into negative and interrogative sentence. For example:

1. (+) Children like playing notebook for the games.

(-) Children don't like playing notebook for the games.

(?) Do children like playing notebook for the games?

14. Arrange these unorganized words in to nominal groups and classify them into its position in the given table below.

1. competitive-second-debate-today-the-national-is-commenced-championship -which

2. Two-historical-the-buildings-famous

3. amazing-he -by -sport-which-first-bought-his-own-money-His-car

4. biggest-and-garden-is-educative-colorful-located-which-in-The-Jalan-Mangunkusumo

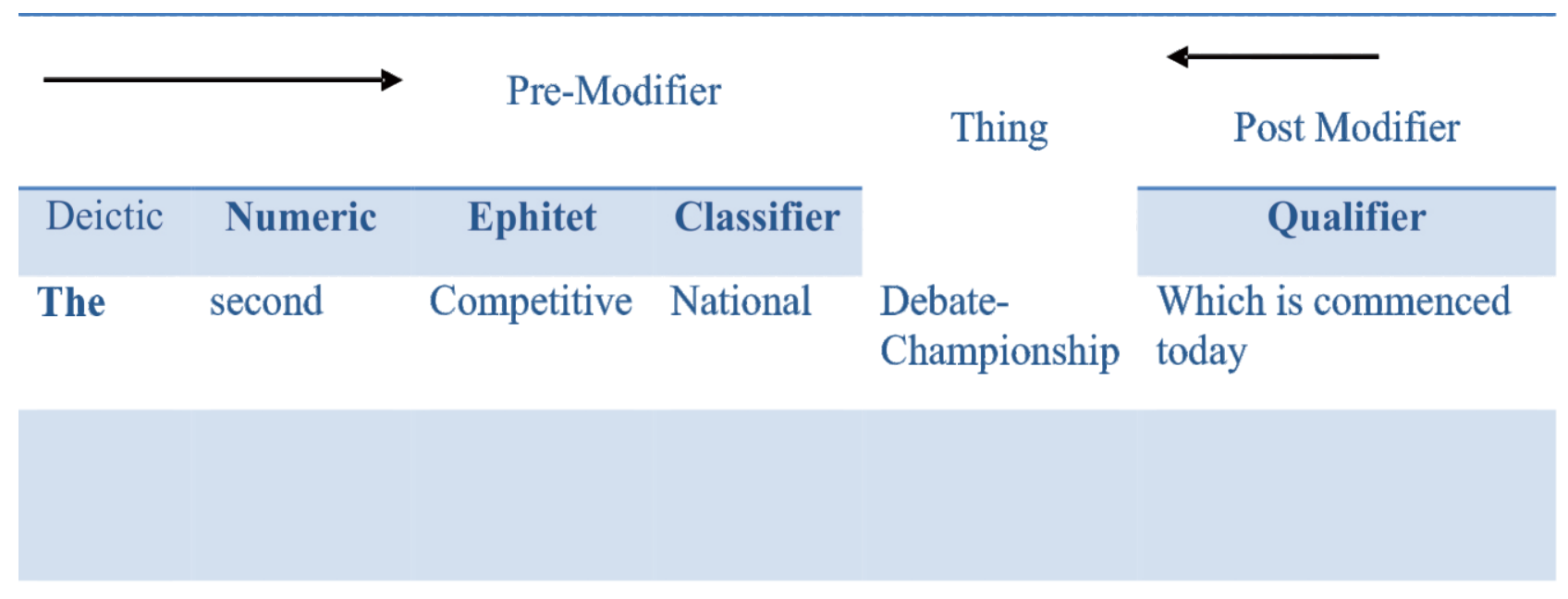

\begin{tabular}{llccrl}
\cline { 5 - 6 } Deictic & Numeric & Ephitet & Classifier & & \multicolumn{1}{c}{ Qualifier } \\
The & second & Competitive & National & $\begin{array}{l}\text { Debate- } \\
\text { Championship }\end{array}$ & $\begin{array}{l}\text { Which is commenced } \\
\text { today }\end{array}$
\end{tabular}




\section{Lats' Talk}

\section{Expressions for Agreeing and Disagreeing}

To make you sound more argumentative, it is important to start your opinion by argumentative expressions as follows:

\section{Stating an Opinion}

- In my opinion

- The way I see it

- According to (an expert),

- As far as I am concerned,

- If you ask me

- In my humble opinion

2. Asking for an Opinion

- How do you think of

- What are your thoughts on

- Do you have anything to say about

- Wouldn't you say

3. Expressing Agreement

- I agree with you

- I couldn't agree with you more

- That is true

- I am second to you

- I have no doubt about that

- I was just going to say that

4. Expressing Disagreement

- I don't think so

- I am afraid I disagree

- I totally disagree

- It is not necessarily

- That is not always true

- I am not sure about that

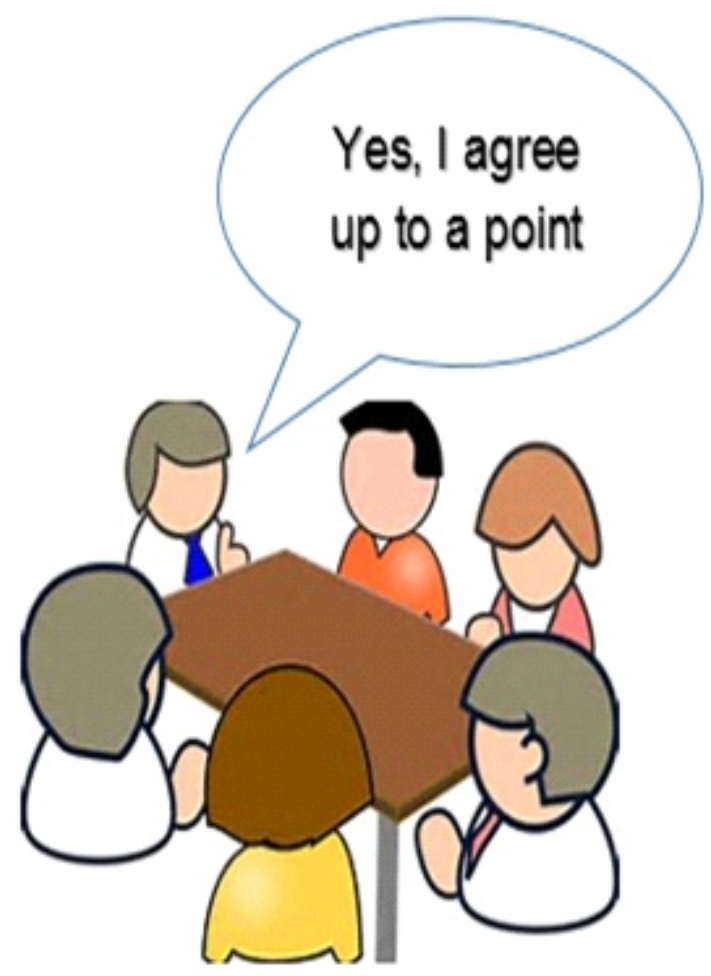




\section{Practice the following debate with your partner.}

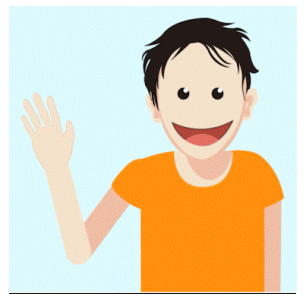

I think that we should not introduce technology especially computers to children

because they are not ready with that.

Why do you think so? I think the best time to introduce technology is when they are still young. Children are just ready with that.

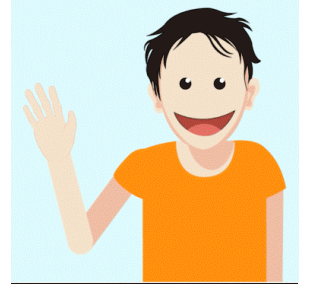

Children don't have self-filter to what they see on computers simply because they don't understand yet.

That is true. But, they can be supervised by their parents, can't they? Children need to know computers so they will be earlier to start learning how to use it properly.

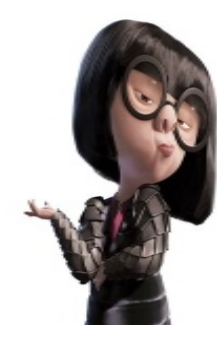

.

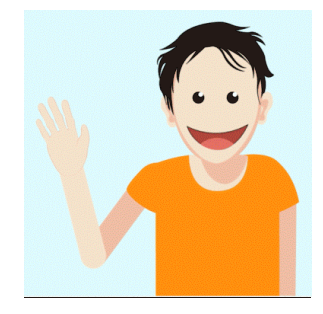
Playing computer is contagious. They want to play it whenever they want. Parents, on the other hand, cannot control them 24 hours a day. They work.

I don't think playing computer is contagious if parents can educate them earlier that they need not to use computer for all along day. Come on. You are overwhelming. 